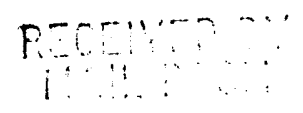

\title{
INITIAL OBJECTIVES OF ON-SITE EMPIRICAL MODELLING OF THERMAL PLUMES: A PRELIMINARY EVALUATION OF A RIVER-SITE AND A LAKE-SITE THERMAL PLUME
}

by

\author{
I. K. Abu-Shumays
}

\section{DISCLAIMER}

Treped as an account of work sponsored by an agency of the United States This report was prepared as an account of work spensored any agency thereof, nor any of their Government. Neither the United States Government nor any agency thereof, nor any or thesponsiemployees, makes any warranty, express or implied, or assumes any legal liability or respons, bility for the accuracy, completeness, or usefulness of any inforinge privately owned rights. Referprocess disclosed, or represents that its use would not infringe privately owed rights Rame, trademark, ence herein to any specific commercial product, process, or se or imply its endorsement, recommanufacturer, or otherwise does not necessarily constivie or imply its enderefer. The views mendation, or favoring by the United States Government ar any state or reflect those of the

and opinions of authors expressed herein do not

ARGONNE NATIONAL LABORATORY

9700 S. Cass Avenue

Argonne, Illinois 60439

Operated by

The University of Chicago under

Contract W-31-109-Eng-38

for the U. S. Atomic Energy Commission

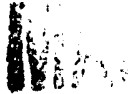


ARGONNE NATIONAL LABORATORY

Applied Mathematics Division

INITIAL OBJECTIVES OF ON-SITE ENPIRICAL MODELLING OF THERMAL PLUNES: A PRELIMINARY EVAIUATION OF A RIVER-SITF AND A LAKE-SITE THERMAL PLUME*

I. K. Abu-Shumays

May 1970

Technical Memorandur No. 198

WWork performed under the auspices of the U.S. Atomic Energy Comission. This report intended for Internal distribution only. 
INITIAL OBJECTIVES OF ON-SITE ERIPIRICAL MODELLING OF TIERMAL PLUNES:

A PRELIMINARY EVALUATION OF A RIVER-SITE AND A LAKE-SITE THERMAL PLUME

$$
\text { I. K. Abu-Shumays }
$$

\begin{abstract}
Th1s report recommends developing a statistical model to characterize the three-dimenslonal'pattern of thermal plumes. It indicates the danger of drawing detailed conclusions on the basis of a small number of observations, and emphasizes the need for proper interpretation of cmpirical measurements. Two reports, on the discharges (1) from the Dresden Power Station Into the IIIInois River and (2) from Waukegan Station Into Lake Michigan are analyzed. In conclusion, a plan for interpretation of temperature measurements is recommended.
\end{abstract}

\title{
1. Introduction
}

An Interdisciplinary group at Argonne is currently Invoived in evaluating the various physical, bjological, chenlcal and metcorological effects of thermal discharges in the Great Lakes, and in particular in Lake Michigan. Lake Michigan ${ }^{1,4}$ Is the sixth largest fresh water lake in the world with a surface area of: 22,400 square miles, an average depth of 276 feet and a volutie of 11.16 cubic miles. The lake has two basins, a southern and a northern basin. Figle 1 indicates that the coastine in the southern basin is very shallow but in the northern basin, it is not quite as regular. Much of the coastline is known to be sandy and forms weak. underwater surfaces not quite suitable for attachment and grovth of aquatic organisms.

Among the sites Argonne has considered modeling is the outfall of Commonwealth Edison's Vaulegan generating station. This is a fossil fuel burning plant whth a discharge canal at the shoreline rather than scme distance out into the lake. In the vicinity of the discharge the lake is very shallow with a depth 
between $3 \mathrm{ft}$ and $6 \mathrm{ft}$. In fact, a $\therefore$ pth of $10 \mathrm{ft}$ exists at a distance not less than 800-1100 ft from the shore 11ne. Hence, we would expect that in this shallow region, the plume will be greatly influenced by local bottom topography, by shore currents (which are not necessar1ly subject to the main movements of the water in the lake), by wind direction and speed, etc. We also expect, because of the limit on the amount of water that could be entrained, that the heated discharge will be carried a maximal distance off shore. This is true unless the plume is deflected towards shore, in which case it will cover a relatively greater distance. Our first main concern is to study the characteristics of the thermal plume. L. P. Beer and W. O. Pipes have done an Initial study of the thermal plume at Waukegan. 3,4 We shail comment on their study in Section 4 below. In order to understand the teciniques of these authors we have found it desirable to comnent on their relevant experimental and analytical work on thermal plumes in rivers. Section 3 is devoted to their study of the effects of discharge of condenser water Into the Illinois River. ${ }^{2}$

\section{Plume Characteristics}

A main objective of on-site empirfcal modelling is to study in detafl. a typlcal thermal plume, its general pattern and the probable changes of this pattern due to various changes in environmental conditions. Analysis of "Heat Dissipation Characteristics" of a representative site would invoive:

1. Temperature distribution study (both spatial and temporal)

2. Exchange coefficient evaluation and correlatfon with wind speeci, direction, topography and other flow cha:acteristics,

3. Temperature statistical analysys,

4. Meteorological and Iimnological statistical analysis. Success in developing a reliable statistical model of the spatial and tomoraz patterns of the plune at different parts of the year for dfffering neteorolog:cal and liriological conditions are very essential for a relfable study of the pingsical, tlological, chemical and meteorological effects of the plume. Our inftial concern 
therefore is to develop a three-dimensional picture of the plume, and to study Its variation with time.

Several analytical and numerical models of plumes already exist, but their universal applicability has not been validated. For example, the excellent study done at Cayuga Lake 5 suggests that when a jet of hot water is dishearged on the surface of relatively deep vater, a discrete surface plume develops and can be characterized by three distinct regions. The first region is the region where the initial momentum of the discharged wi.ter dominates. In this region, turbulent mixing dilutes the warm water of the plume by the horizontal and vertical entrainment of ambient colder vater into it. The rate of vertical entrainment is proportional to the Jocal value of the bulk Richardson number $B$, defined as 5

$$
B=\frac{g h}{V^{2}} \frac{\rho_{a}-\rho}{P_{a}}
$$

Here $\rho, h$ and $v$ are suitable average values of the density, thickness and velocity of the plume relative to the amblent vater and $p_{a}$ is the density of the amblent water. The Richardson number $\mathrm{b}$ initially increases as the velocity decreases. The vertical entrainment ceases and the first region ends when $B$ reaches a critical value $B_{c}=0.8$, The second region is a diffusion convection reglon. In this region, because of buoyancy gradients, there is no vertical entrafnment; but horfzontal entralnment from the clges continues. In this region the velocity of the plume tencis to a constant value appropriate to that of the ambient current. Since

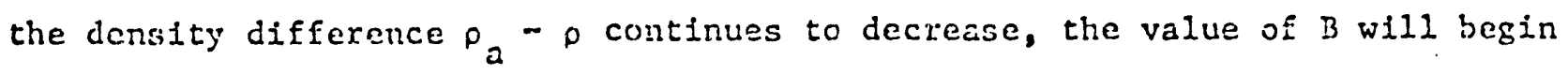
(and then continue) to decrease. Vertical entrainment sets in again wher $B$ falls belo: $\mathrm{B}_{\mathrm{c}}=0.8$ and this characterizes the beginning of the thi.rd region.

What we would expect on the basis of our limited knowledge is that the vertical cross sections away from the polnt of the discharge will look as shown In Fig. 2. Once ve know the bounatitis of like nime, then we can analyze to advantage the vacious cociing mechanisnc including sutrainment, heat exchange with the atmosphere 
etc. Except posstbly in the third region, the boundarles of the plume would typlcally be characterized by one or all of the following factors: large temperature difference, large density difference, possibly large current difference (local motion of water in the plume in opposite direction to that of the amblent water) and turbulence at the edges where entrainment takes place. It is valuable to check whether or not the edges of the plume can be localized experimentally. of course isotherms should give us a good idea of the shape of the plume.

\section{Evaluation of a River-site Study ${ }^{2}$}

In the Fall of 1968, L. P. Beer, W. O. Plpes and a group of supporting engineers and scientists carried out what seemed to bc an initial in-depth investigation of. the effects of heated water discharges of the Dresden Station power plant on the Illinols River. ${ }^{2}$ We shall not be concerned here with thelr evaluation of the effects on the aquatic environment of the Illfnois, but rather with their conclusions regarding the characteristic of the thrce-dinensfonal plume they analyzed. It should be emphasized that taking 1nto account the short time limitation of their study and the srall number of measurements they vere able to make, their results are indicative of the characteristics of the plume (the same conclusion applies to their evaluation of the "Walkegan Station" discharges quoted below). However, their conclusions regarding the actual shape of the plume are crroneous, and as such, cannot be fustified on the basis of their data.

As is shown In Figure 3, the Desplainas River and the Rankake Rivei foin to form the Illinols River. The Desplaines River hns a rate of flow nomally 3 to 9 times greater than that of the Kankakec. In October 1963, its vaters viere also $5-8^{\circ} \mathrm{F}$ varmer. ${ }^{2}$ The analysis of Dresclen station plume is complicatad because of Its location in the vicinity of the confluence of these two rivers, In fact, we expect classical nethods of analysis to break down in sich a situation. The study of Becr and Plpes in the Dresden pool in October 1968 indicates the existence of a vertical thermoline together with horfontal and vertical stratificaticn. 
Beer, et al., neasured, among other things, water temperatures at various positions at various depths in the DesPlaines, Kankakee and Illinois rivers, of Interest to us are the posjtions in the neiflborhood of the power plant discharge, shown in Fig. 7. Beer, et al., conclude that the resulting tenperature isotherms at $1 \mathrm{ft}, 4 \mathrm{ft}$, and $8 \mathrm{ft}$ below the river surface are as shown in Figs, 4, 5, and 6. Note that these figures indicate that the hot vater jet is restricted to a depth less than $4 \mathrm{ft}$ up to a distance of about 300-400 ft, and then dips to a depth of $8 \mathrm{ft}$. Cur initial reaction was to justify such a phenomenon. If ve assune that the thamal fet influences and is influenced by the existerce of a vertical thermocline, then it is not unreascrable to observe a dfp of the thermal jet. Figures 4-6 also indicate that the hot water spreads towards the north shote and, possibly becasse of vater currerts and horizontal stratification, it is reflected to the deoper lryers. As a result, warmex vater at $74^{\circ} \mathrm{F}$ exists below cooler $72^{\circ} \mathrm{F}$ water.

The relevant measurements taken by Beer, 드 al., are reproduced ir Table I. As can be castly checked; none of their measurements justifics the actuai detrijs. given in F1gs 4-6 or the interpretation given above. With the exception of the measurement of position 21, Table I Indicates that the temperature is uniforn in denth only at a fer isolated locations and in alizost all. the jocations, the cer-

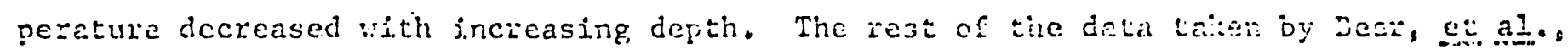
which have not been quoted here also inply that the temperature decreases vith dejti. This inplication regarding temperature gradient variation in depth, can ccicoivoly

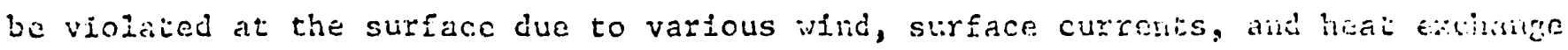
phennalena, but, under normal conditions ne do not expect a violation of tists observation at greater depth.

Since the mersurements of Beer et a1., are by necessity not struttancous; the finctuation at any ore polnt gives an indication of the arro: involvec in con reating the veriols messurnents. For example, the measurement at position 24 incicate: that

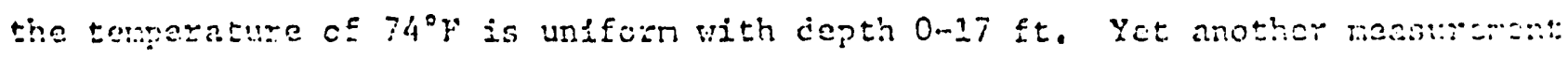

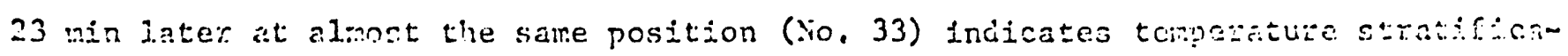
tion with deptis with $\Delta t=2.5^{\circ} \mathrm{F}$, fron ton to bottem. 
In conclusion, Beer, et al., have selected a difficult site to model. Because of the time limitation of their study, they vere unable to carry out all the desirable measurements; furthermore, they did not properly interpret their temperature data. Agaln, we have no comments on the major part of their report ${ }^{2}$ dealing with the biological and chemical effects of the condenser water discharge.

\section{Evaluation of a Lake-Site Study ${ }^{3}$}

This section is restricted to the parts of the study by Beer, et al. 4 dealing with the three-dimensional characteristics of the Commonrealth Edison Waukegan generating station plume. The study of Beer, et al., performed in April 1968 gives a reasonable estimate of the dimensions of the plume for a particular time of the year and a particular meteorological condition. Their report Includes a representative sample of numerical and graphlcal results including Figs. 8 and 9 reproduced in this report. Fig. 8 and the rest of the figures given by Beer, et al.., seem to Indicate that $54^{\circ} \mathrm{F}$ cold water is trapped and is floating on top of warter water. Wille it is possible to have cold water on top of hot vater for extended periods of time, due to combination of wind and current effects, such instabilities as indicated by FIg. 8 can hardly be expected to last during the twoor-more-hour period of the measurement. Figure 9 indicates the positions of temperature measurements, the numerical order in which these neasurements were taken, and explains one of the sources of difficulty. The relevant measurements at positions 1, 2, ? we:e carried out at 8:30-8:40 a.m. (April 30, 1968) winen the water circulation was $699,000 \mathrm{gmm}$; at positions 14,15 at 9:25 9:30 a.m.; and at positions 35,36 at time 10:25-10:30 a.m. when the water circulation was increased to 763,000 to mainiain a $\Delta t$ of $122^{\circ} \mathrm{F}$. Changes in vind velocities of about $5 \mathrm{mph}$ are reported but no measurements of water currents seen to have been taken. In sumtary, instead of concentrating on the near-shore region and performing as many measurements as possible to isct a meaningful idea of 1ts characteristics and then moving to other regicns, Benr, et al., elected to traverse the whole plume from 
near region to far region and repnat the traverses at time intervals where the plume can yery well change, particularly in the region close to the outfall. Rapid changes could not be ruled out if we note that the vicinity of the outfall seems to have an irregular bottom topography and that the vater up to $800 \mathrm{ft}$ from shore is very shallow, with depth ranging from 3 to $6 \mathrm{ft}$. Local currents and waves are usually highly variable over this raige. We have plotted Fig. 10 on the bases of the data given by Beer, et 2 l., to estimatc the botton contours for the laukegan plume.

Other temperature measurenents were made by the FIPCA ${ }^{6}$ but are admittedly irsufficient for an accurate characterization of the plume.

\section{Conclusion and Recormendations}

We conclude from the above that for on-site modelling of a particular plune, f.t is essential to take into conslderation the varlous factors affecting the heat exchange mechanism and the spatial and temporal structure of the plume, including bottom toporraphy, local curients and wind divection, temperature, velocity, etc. It is also essential, to be able to model each zone separately, to repeat some measurements to estfiate cirors and fluctuation;, and to fnterpiret empirfcal measurements (or their averages) properly.

For nodaling of hot viates discharge patterns, such as the Waukegan plune with a disciares canal at the sialics shoreline of the southern basin of Lalie Michigan for example, we recontend the develonititit of cietafled contours of botton topography.

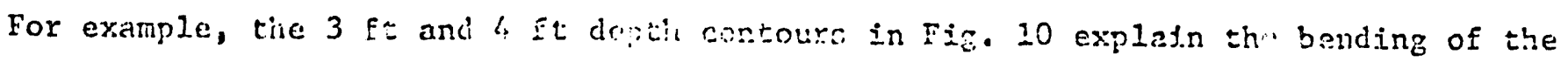
plume in Fig. E In a direction chosite to that of the wind at the time of the measurement. Such contouts and bottrm irregtlarities nay prove advantageous for determining refezence ponfisons fou majuzencats.

At line present; as ing as we know, the three-dimensionai pattern of the Waukejan ilut: aporud oy nect,

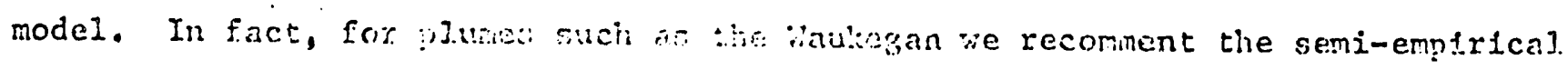

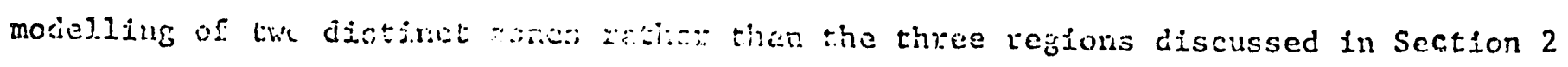
above: Zone $I$, a shajion water wone ir vich the rajor part of the plume is in cortact 
with the bottom sediments; Zone II, a deep water zone in which the plume is over amblent water. For the Waukegan plant, the Beer, et al., report suggest. to us that in Zone. II the temperature difference is relatively smal1, the relative velocity is very small (probably negligible at a depth o: 14 or more feet below the surface) and that the effect of gravitation is dominent. We also expect that the wind and current conditions may sometimes be such as to drive the plume to the shore in Zone I (the north shore for the Waukegan plant) and thus to extend Zone I for a rather long distance at the shore. If such a situation is undesirable, then a different design of the outfall or two breakwaters on both sides of the outfall will help to push the plune to zone II.

Finally, to aid the semi-cmplrical treatment, we plan to develop a computer program which rould require as input the time and position of each measurement, the errors in the position and in the measurement, and other variables such as currents, wind velocities, etc. The program would then correlate the various measurements, use physically reanirgful constraints such as admissibie temperature gradients in depth, and yield two-dimensional isotherms, the areas betreen isotherms, and posstbly the volume of vater within $\Delta T$ of a specified temperature $T$. The experience of D. L. Phillips and the author in smoothing techniques (regularizarfon technigques) way prove useful in this conrection.

\section{ACKNOIILDG:IENTS}

The author is grateful for the helpful commerts he reccived from J. Asbury, J. Carson, P. Gustafson, B. Hoglund, T. Hughes, H... Moses, D. Phillips, Y. Prastein, G. Romberg, A. Szewczyk, I. ïckar and R. Wessel. 


\section{REFERENCES}

1. J. G. Asbury, "Evaluating the Effects of Thermal Discharges on the Energy Budget of Lake Michigan," Argonne National Laboratory Report (to be published).

2. L. P. Beer and W. O. Pipes, "The Effects of Discharge of Condenser Water Into the Illinois River," Industrial BIO-IEST Lab. Inc. Report No: IBT-W7178, June 1969.

3. L. P. Beer and W. O. Pipes, "A Practical Approach: Environmental Effects of Condenser Water Discharge in Southwest lake Michigan," Industrial BIO-TEST Lab. Inc., no date glven.

4. F. W. Kittrell, "Pollution of Lake Michigan and Its Tributary Basin," Proceedings, Vol. 2, U.S. Department of the Interior, Fuderal Vater Poilution Control Administration (Feb. 25, 1969).

5. T. R. Sundaram, C. C. Easterbrook, K. R. Piech, and G. Rudinger, "An Investigation of the Physlcal Effects of Thermal Disciharges into Cayuga Lake (Analytical study)," CAL Report lo. VT-2616-0-2, November 1969.

6. U.S. Department of the Interior, "prejliminary Samping Survay, Waulkegan and Zion Power Plant Sites," FTQA, Lake Michigan Basin Office, Chicago, Apri1 1970. 
Table I. ILLINOIS RIVER STUDY - OCTOBER 2, 1968

LOCATIONS, WEATHER, TEMPERATURE DATA

(Water Circ. $166,000 \mathrm{gpm}$, Water Temperature at

Inlet $70^{\circ} \mathrm{F}$ and at outlet $82^{\circ} \mathrm{F}, \Delta T=12^{\circ} \mathrm{F}$ ).

\begin{tabular}{|c|c|c|c|c|c|c|c|c|c|}
\hline $\begin{array}{l}\text { Position } \\
\text { No. }\end{array}$ & $\begin{array}{c}\text { PM } \\
\text { Time }\end{array}$ & $\begin{array}{l}\text { Straight Line } \\
\text { Distance From } \\
\text { Discharge Outfall }\end{array}$ & $\begin{array}{l}\text { Depth } \\
\text { (Ft.) }\end{array}$ & $\begin{array}{l}\text { Wate } \\
\text { of a }\end{array}$ & $\begin{array}{l}\text { I Temp } \\
\text { Ft. - D }\end{array}$ & $\begin{array}{l}\text { p. } \\
\text { Jepth }\end{array}$ & $\begin{array}{l}\quad \text { Wir } \\
\text { Vel. } \\
\text { (mph) }\end{array}$ & $\begin{array}{l}\text { Direct. } \\
\text { (Deg.) }\end{array}$ & $\begin{array}{l}\text { Air } \\
\text { Temp. } \\
\left({ }^{\circ} \mathrm{F}\right)\end{array}$ \\
\hline 18 & $3: 30$ & 85 & 9 & $\begin{array}{l}76 \\
74\end{array}$ & $\begin{array}{l}0 \\
7\end{array}$ & $\begin{array}{l}0-7 \\
7-9\end{array}$ & 26 & 180 & . \\
\hline 19 & $3: 32$ & 171 & 9 & $\begin{array}{l}76 \\
75 \\
73\end{array}$ & $\begin{array}{l}0 \\
4 \\
6\end{array}$ & $\begin{array}{l}0-4 \\
4-6 \\
6-9\end{array}$ & 14 & 240 & \\
\hline 20 & $3: 35$ & 215 & 9 & 73 & & $0-9$ & 20 & 225 & \\
\hline 21 & $3: 37$ & 310 & 8 & $\begin{array}{l}78 \\
70 \\
?\end{array}$ & & $\begin{array}{l}0-2 \\
2-4 \\
4-8\end{array}$ & 20 & 210 & \\
\hline 22 & $3: 39$ & 529 & 10 & $\begin{array}{l}76 \\
75 \\
73 \\
72 \\
71 \\
70 \\
69 \\
\end{array}$ & 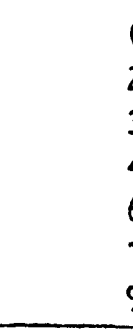 & $\begin{array}{l}0-2 \\
2-3 \\
3-4 \\
4-6 \\
6-7 \\
7-9 \\
0-10\end{array}$ & 17 & $\because 220$ & \\
\hline 23 & $3: 42$ & 585 & 13 & $\begin{array}{l}74 \\
73 \\
72\end{array}$ & $\begin{array}{l}0-3 \\
3-9 \\
9-13\end{array}$ & & 25 & 215 & . \\
\hline 24 & $3: 46$ & 720 & 17 & 74 & $0-17$ & & $2 i$ & 210 & \\
\hline 25 & $3: 48$ & 630 & 13 & $\begin{array}{l}73 \\
70 \\
69 \\
68\end{array}$ & $\begin{array}{l}0-9 \\
9-11 \\
11-12 \\
12-12\end{array}$ & & 23 & 225 & \\
\hline 26 & $3: 50$ & 505 & 8 & 68 & $0-8$ & & $2 s$ & 230 & 77 \\
\hline 27 & $3: 50$ & 310 & 8 & 68 & $0-8$ & & 28 & 230 & \\
\hline 28 & $3: 54$ & $3 ! 5$ & 9 & $\begin{array}{l}77.5 \\
77 \\
75 \\
67\end{array}$ & $\begin{array}{l}0-3 \\
3-5 \\
5-7 \\
7-9\end{array}$ & & 25 & 232 & \\
\hline
\end{tabular}

it Note that the straight line distance firorn ousfon! is hut mearinivi

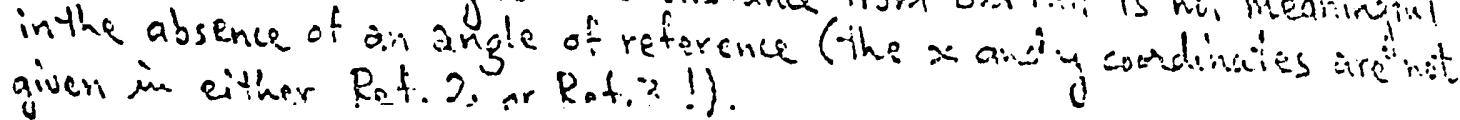




\section{Table I (cont.1)}

\begin{tabular}{|c|c|c|c|c|c|c|c|c|}
\hline $\begin{array}{l}\text { Position } \\
\text { No. }\end{array}$ & $\begin{array}{r}P M \\
\text { Time }\end{array}$ & $\begin{array}{l}\text { Straight Line } \\
\text { Distance From } \\
\text { Discharge Outfall }\end{array}$ & $\begin{array}{l}\text { Depth } \\
\text { (Ft.) }\end{array}$ & $\begin{array}{l}\text { Water } T e \\
{ }^{\circ} F \text { at Ft. }\end{array}$ & $\begin{array}{l}\text { np. } \\
\text { Denth }\end{array}$ & $\begin{array}{l}\text { W } \\
\text { Vel. } \\
\text { (mph) }\end{array}$ & $\begin{array}{l}\text { Direct. } \\
\text { (Deg.) }\end{array}$ & $\begin{array}{l}\text { Air } \\
\text { Temp. } \\
\left({ }^{\circ} F\right)\end{array}$ \\
\hline 30 & $4: 00$ & 395 & 9 & $\begin{array}{l}77.5 \\
77\end{array}$ & $\begin{array}{l}0-1 \\
1-9\end{array}$ & 15 & 240 & 73 \\
\hline 31 & $4: 03$ & 555 & 7 & $\begin{array}{l}74 \\
73.5 \\
73 \\
71.5 \\
71 \\
\end{array}$ & $\begin{array}{l}0-2 \\
2-3 \\
3-4 \\
4-5 \\
5-7 \\
\end{array}$ & 8 & 210 & . \\
\hline $\begin{array}{r}33 \\
\vdots \\
\vdots \\
\vdots \\
\end{array}$ & 4:09 & 720 & 17 & $\begin{array}{l}75 \\
74 \\
73.5 \\
72.5\end{array}$ & $\begin{array}{l}0-7 \\
7-9 \\
9-13 \\
13-17\end{array}$ & 9 & 232 & . \\
\hline 34 & $\begin{array}{l}4: 11 \\
\end{array}$ & $\begin{array}{r}897 \\
\therefore\end{array}$ & 17 & $\begin{array}{l}74 \\
72 \\
71 \\
70\end{array}$ & $\begin{array}{l}0-8 \\
8-9 \\
9-16 \\
16-17\end{array}$ & 10 & 210 & 74 \\
\hline 35 & $\because 15$ & 944 & 18 & $\begin{array}{l}74 \\
73 \\
72 \\
70.5 \\
70 \\
69.5 \\
\end{array}$ & $\begin{array}{l}0-6 \\
6-7 \\
7-8 \\
8-10 \\
10-17 \\
17-18 \\
\end{array}$ & 21 & 180 & \\
\hline 36 & $4: 16$ & 1075 & 17 & $\begin{array}{l}74.5 \\
73.5 \\
73 \\
71.5 \\
71 \\
69.5\end{array}$ & $\begin{array}{l}0-5 \\
5-6 \\
6-7 \\
7-8 \\
3-11 \\
11-17\end{array}$ & 15 & 229 & \\
\hline 37 & $<: 19$ & 990 & 16 & $\begin{array}{l}74 \\
73 \\
72 \\
71 \\
69.5\end{array}$ & $\begin{array}{l}0-6 \\
6-9 \\
8-9 \\
9-10 \\
10-16\end{array}$ & 23 & 233 & \\
\hline 38 & $4: 22$ & 1070 & 17 & $\begin{array}{l}74 \\
71.5 \\
71 \\
70.5\end{array}$ & $\begin{array}{l}0-12 \\
12-13 \\
13-14 \\
14-17\end{array}$ & 24 & $2 \leq 0$ & 75 \\
\hline 1 & $4: 33$ & 849 & 18 & $\begin{array}{l}73.5 \\
73 \\
7 ! \\
69.5\end{array}$ & $\begin{array}{l}0-11 \\
11-15 \\
15-16 \\
15-18\end{array}$ & 15 & 197 & \\
\hline
\end{tabular}


Table 1. (Cont. 2)

\begin{tabular}{|c|c|c|c|c|c|c|c|c|}
\hline $\begin{array}{l}\text { Position } \\
\text { No. }\end{array}$ & $\begin{array}{r}\text { PM } \\
\text { Time }\end{array}$ & $\begin{array}{l}\text { Straight Linc } \\
\text { Distance From } \\
\text { Discharge Outínll }\end{array}$ & $\begin{array}{l}\text { Depth } \\
(\text { I.t. })\end{array}$ & $\begin{array}{l}\text { Watcr T } \\
{ }^{\circ} \mathrm{F} \text { at } \mathrm{Fl}\end{array}$ & 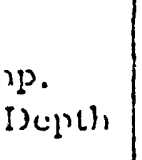 & $\begin{array}{l}\text { W } \\
\text { Vcl. } \\
\text { (mpil) }\end{array}$ & $\begin{array}{l}\text { nd } \\
\text { Direct. } \\
\text { (I)eg. }\end{array}$ & $\begin{array}{l}\text { Air } \\
\operatorname{T(n)}) \\
\left({ }^{\circ} F\right)\end{array}$ \\
\hline 42 & $4: 37$ & 761 & 17 & $\begin{array}{l}73.5 \\
73 \\
72 \\
71\end{array}$ & $\begin{array}{c}0-10 \\
10-11 \\
11-13 \\
13-17\end{array}$ & 17 & 220 & \\
\hline 43 & $4: 40$ & 851 & 19 & $\begin{array}{l}74 \\
73 \\
72.5 \\
\end{array}$ & $\begin{array}{l}0-11 \\
11-13 \\
13-19\end{array}$ & 15 & 253 & \\
\hline 44 & $4: 45$ & 973 & .18 & $\begin{array}{l}74 \\
73 . \\
72 \\
71.5 \\
70.5 \\
69.5\end{array}$ & $\begin{array}{l}0-9 \\
9-10 \\
10-11 \\
11-15 \\
15-16 \\
16-18\end{array}$ & 18 & 220 & \\
\hline 45 & $4: 52$ & 1085 & 18 & $\begin{array}{l}73 \\
72 \\
71 \\
70.5 \\
70\end{array}$ & $\begin{array}{l}0-5 \\
5-5 \\
6-3 \\
8-11 \\
11-18\end{array}$ & 18 & 210 & \\
\hline 48 & $5: 01$ & 546 & 6 & 72. & $0-6$ & 15 & 242 & \\
\hline 49 & $5: 04$ & 556 & 10 & $\begin{array}{l}73 \\
72.5 \\
72 \\
71.5 \\
71\end{array}$ & $\begin{array}{l}0-4 \\
4-5 \\
5-6 \\
6-8 \\
5-10\end{array}$ & 20 & 249 & \\
\hline 50 & $5: 07$ & 686 & 15 & $\begin{array}{l}75 \\
\therefore .3 \\
74 \\
73 . \\
73 \\
72\end{array}$ & $\begin{array}{l}0-1 \\
1-4 \\
4-7 \\
7-11 \\
11-12 \\
12-15\end{array}$ & 12 & 195 & . \\
\hline 51 & $5: 10$ & 840 & 18 & $\begin{array}{l}73.5 \\
73\end{array}$ & $\begin{array}{l}0-10 \\
20-:\end{array}$ & $17^{\circ}$ & 213 & \\
\hline 52 & $5: 12$ & 592 & 13 & $\begin{array}{l}74.5 \\
73.5 \\
73 \\
72.5 \\
\end{array}$ & $\begin{array}{l}0-7 \\
7-10 \\
20-11 \\
11-13 \\
\end{array}$ & is & $2 \leq 9$ & \\
\hline 53 & $5: 15$ & $481^{\circ}$ & 10 & $\begin{array}{l}74 \\
73 \\
72\end{array}$ & $\begin{array}{l:}0-7 \\
7-3 \\
8-10\end{array}$ & 24 & $\therefore 10$ & \\
\hline 54 & $5: 17$ & 150 & 8 & $\begin{array}{l}73 \\
72.5 \\
72\end{array}$ & \begin{tabular}{l|l}
$0-1$ & \\
$j-3$ & $\vdots$ \\
$j-8$ &
\end{tabular} & 3́: & 22.3 & \\
\hline
\end{tabular}




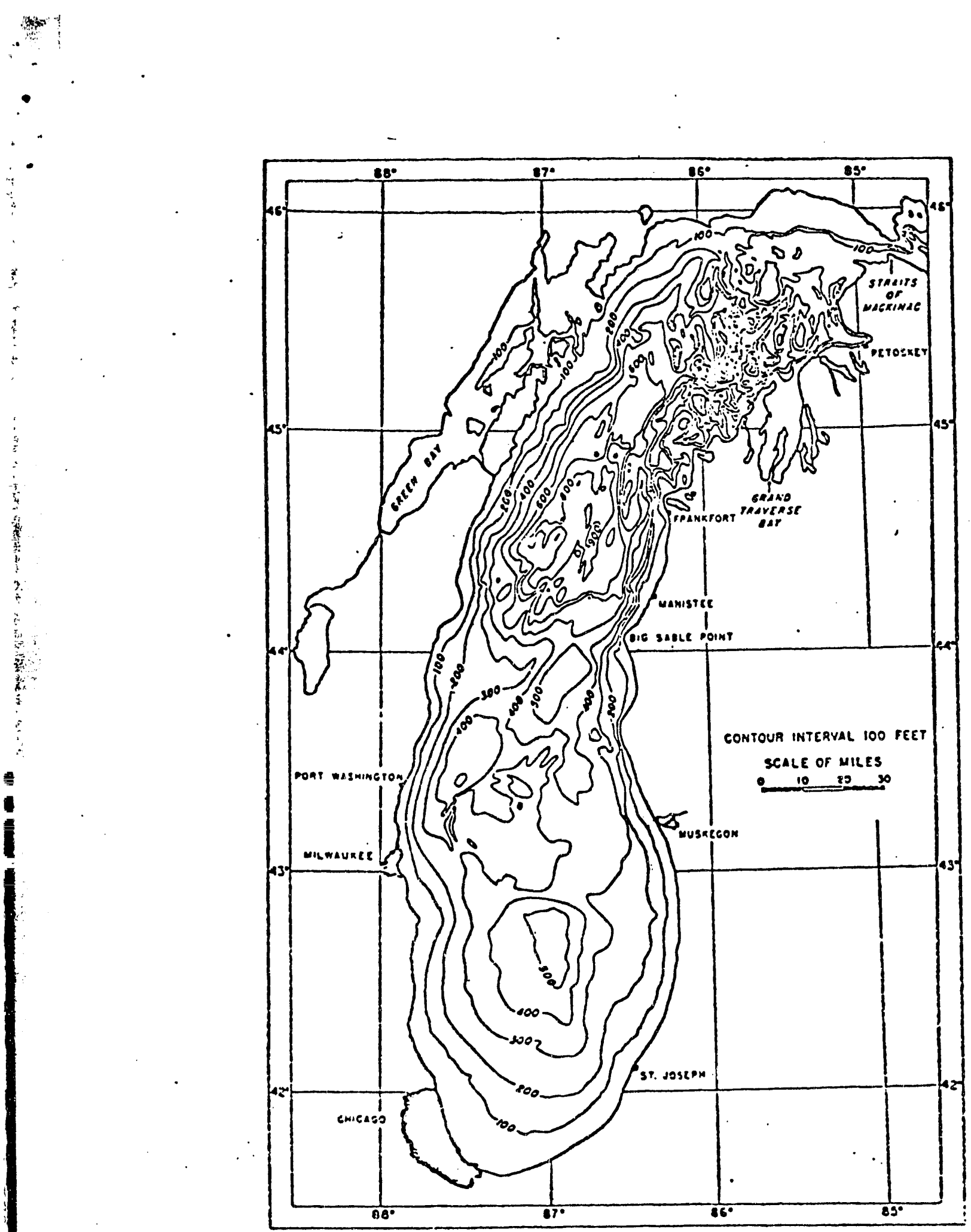

SOUACE: Reprinted from Geology of the

Fig1. BOTTOM TOFOGRAPHY Great Lakes, by jack L. Hough. 


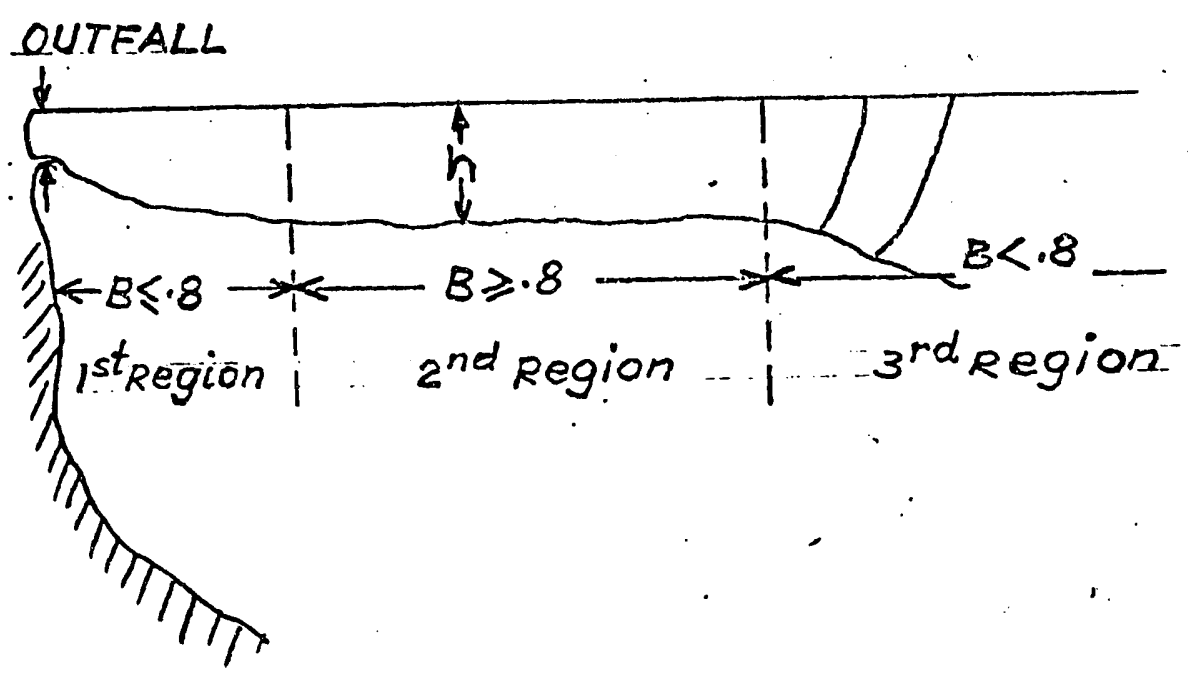

$\therefore$ a) $x=z$ Cross section
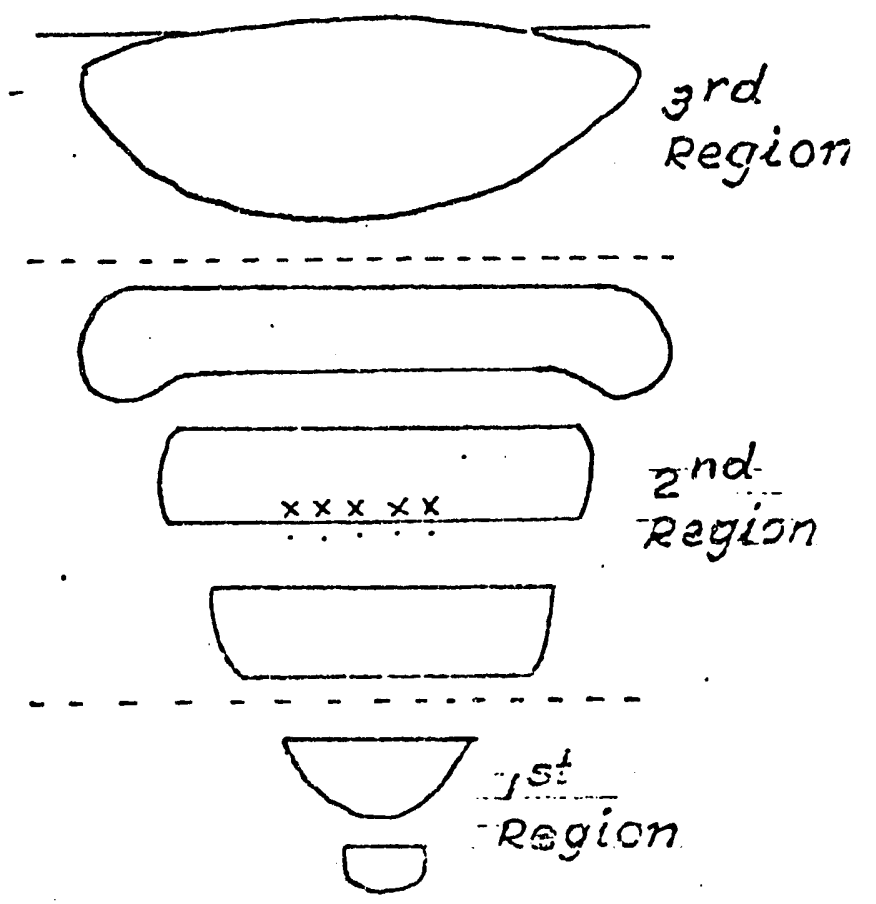

b) $y=z$ cross section

FIG .2 Anticipated vertical cross-sections of the plume over deep waters 


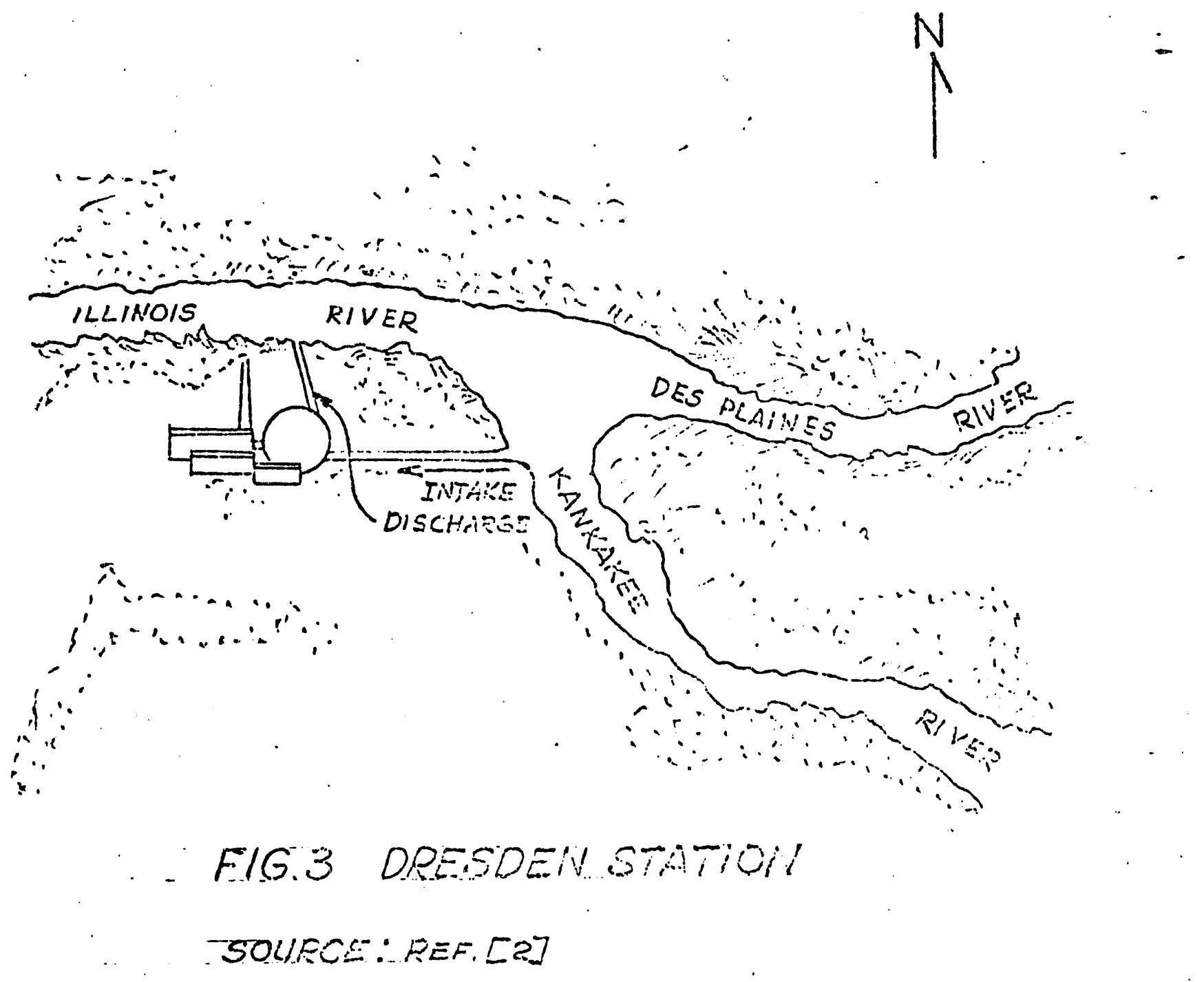




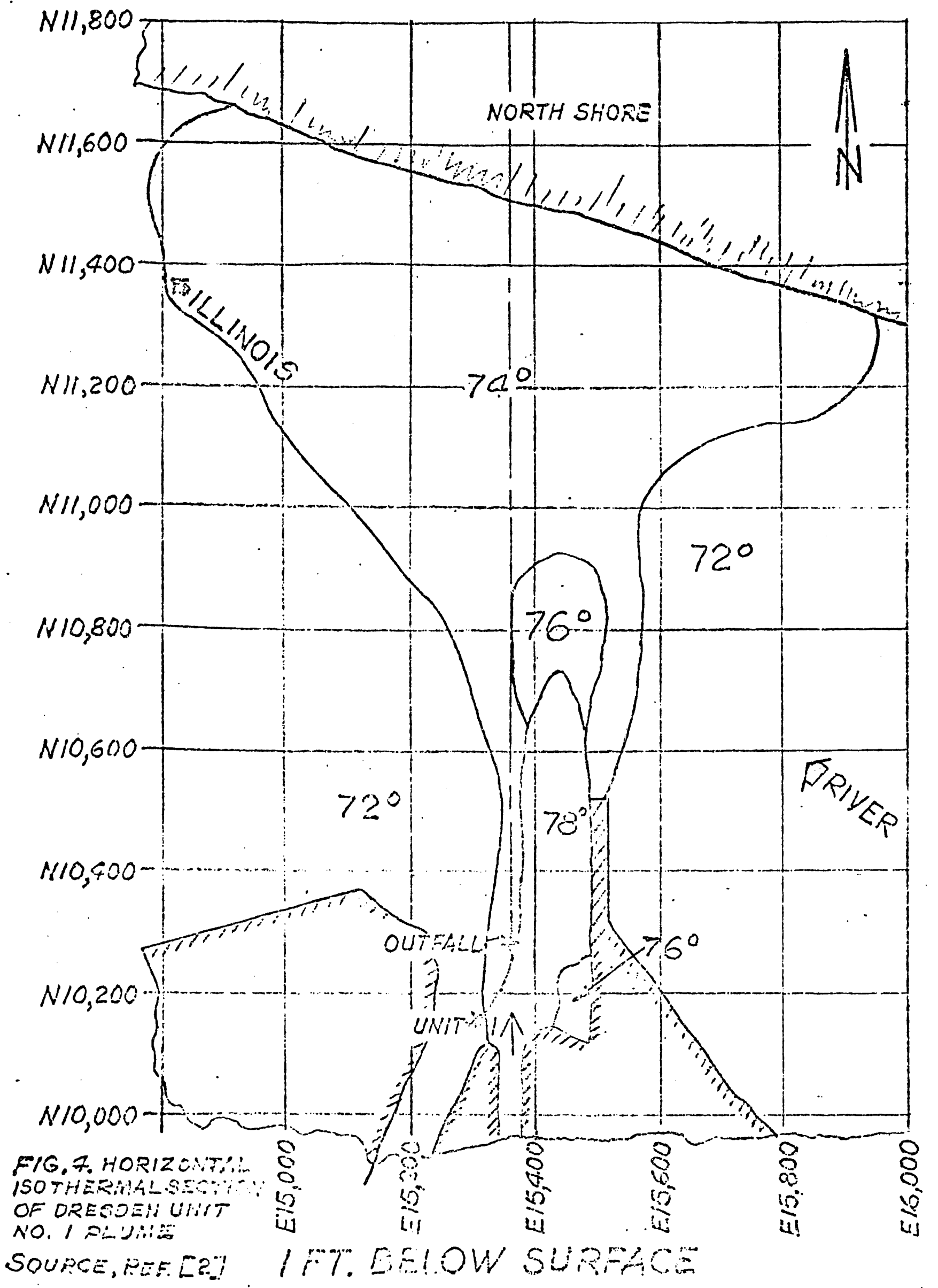




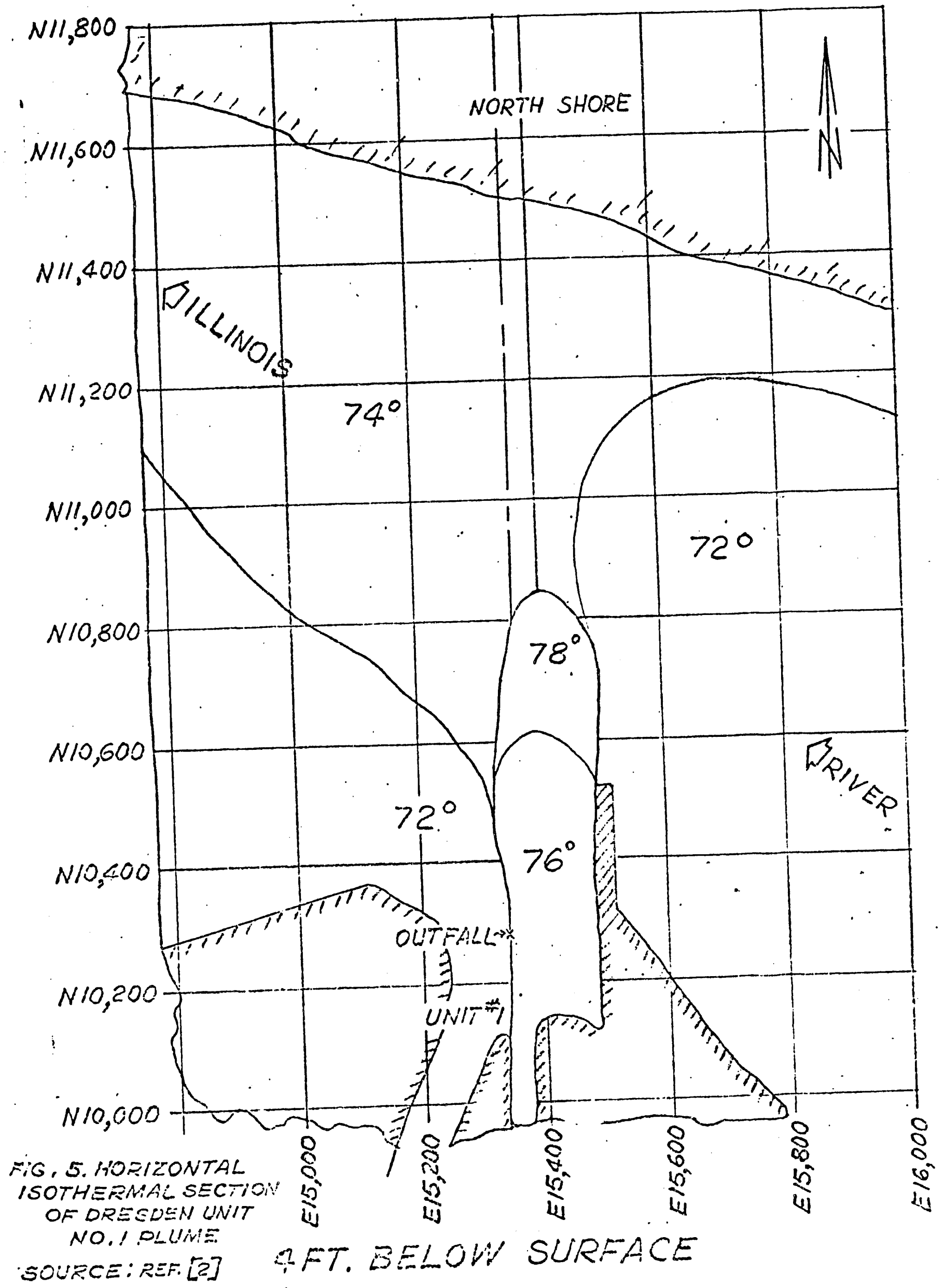




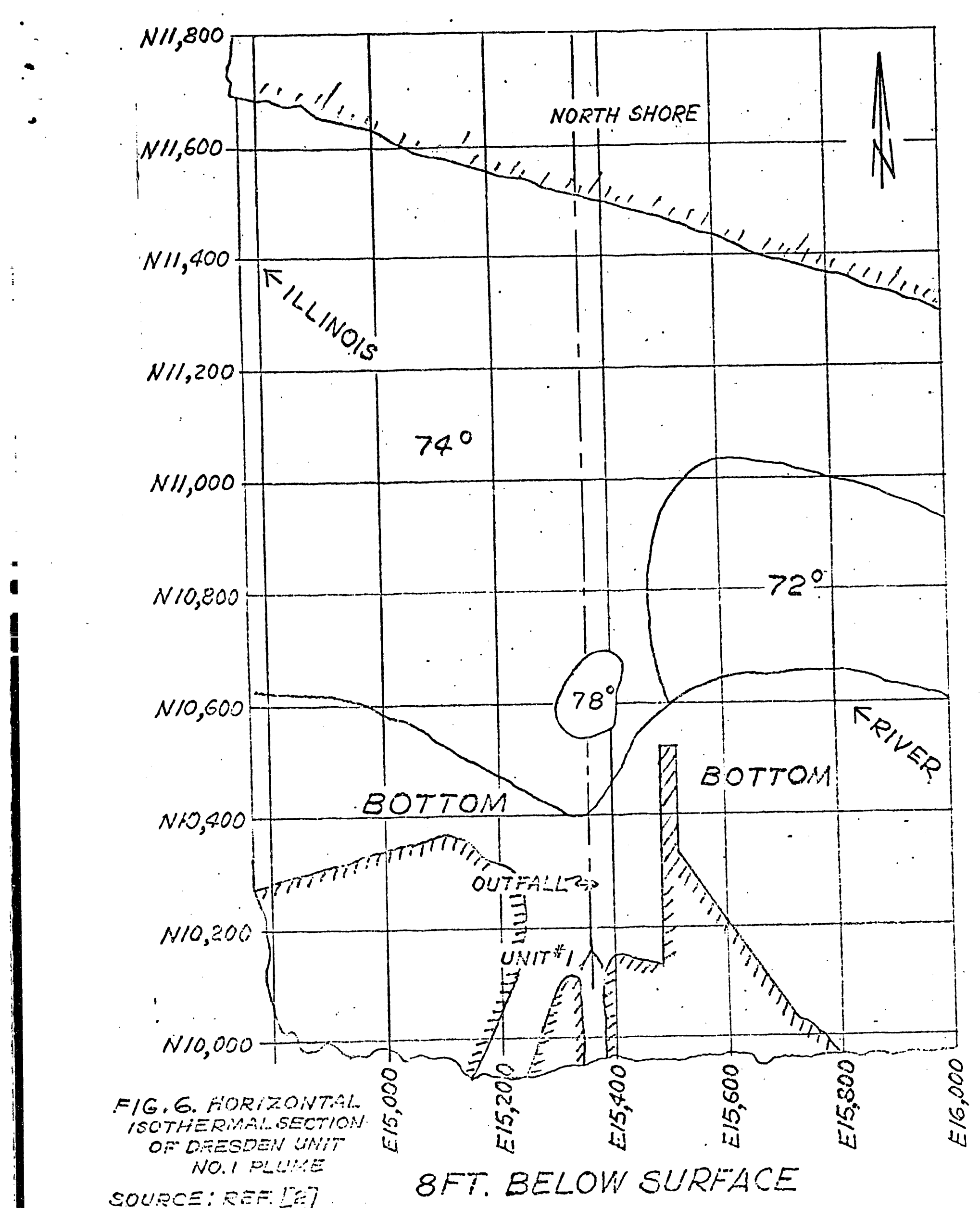




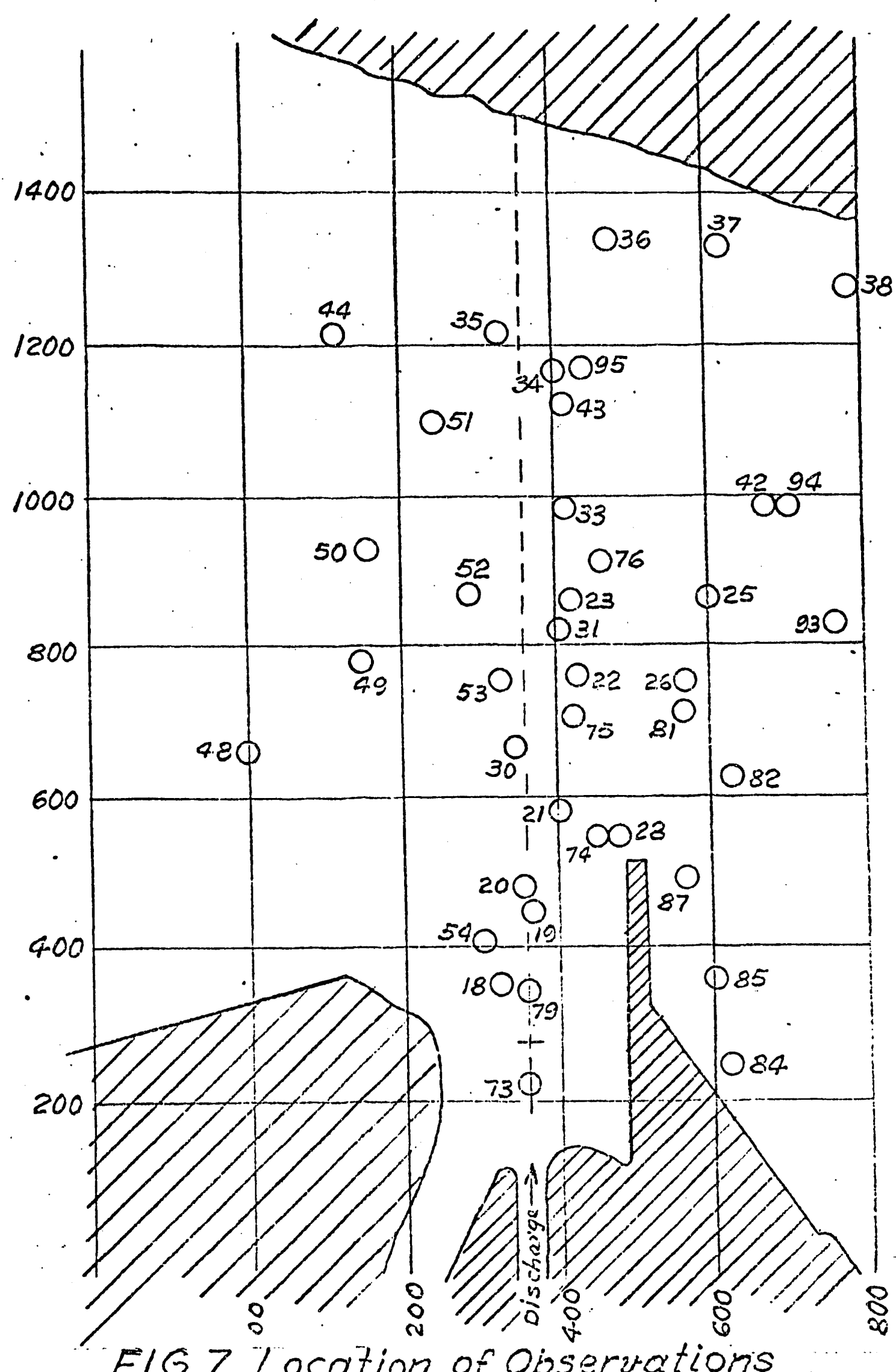




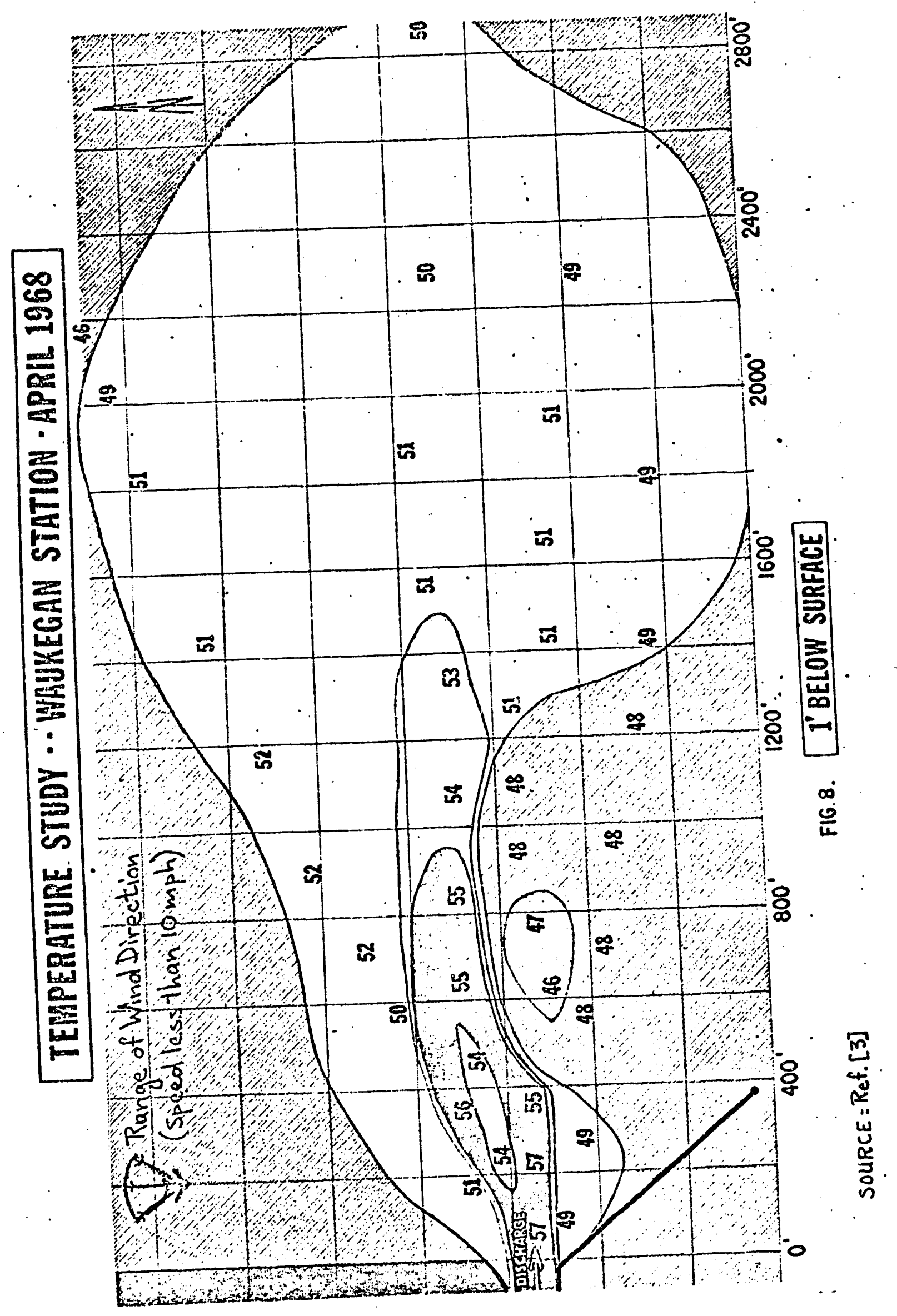




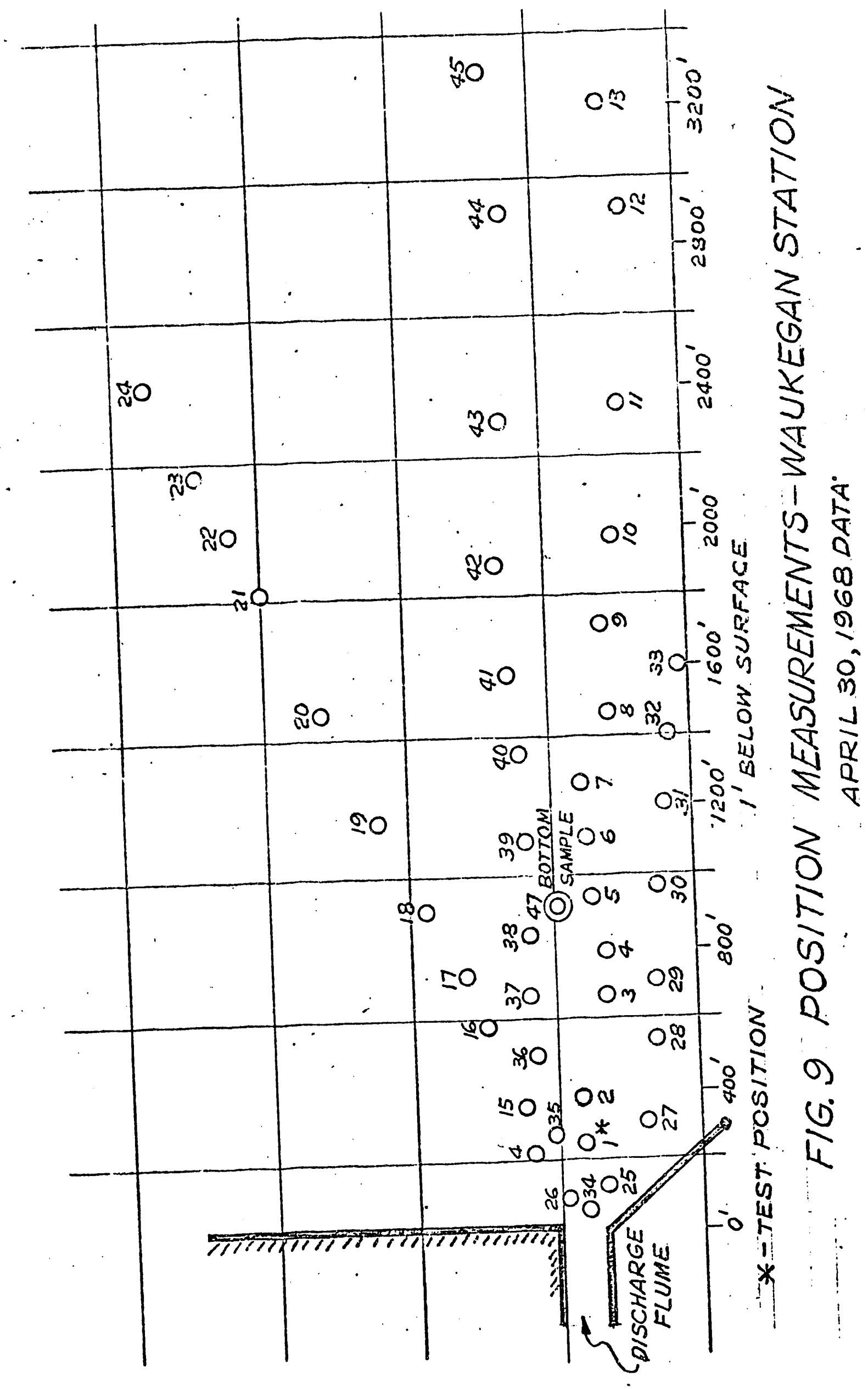




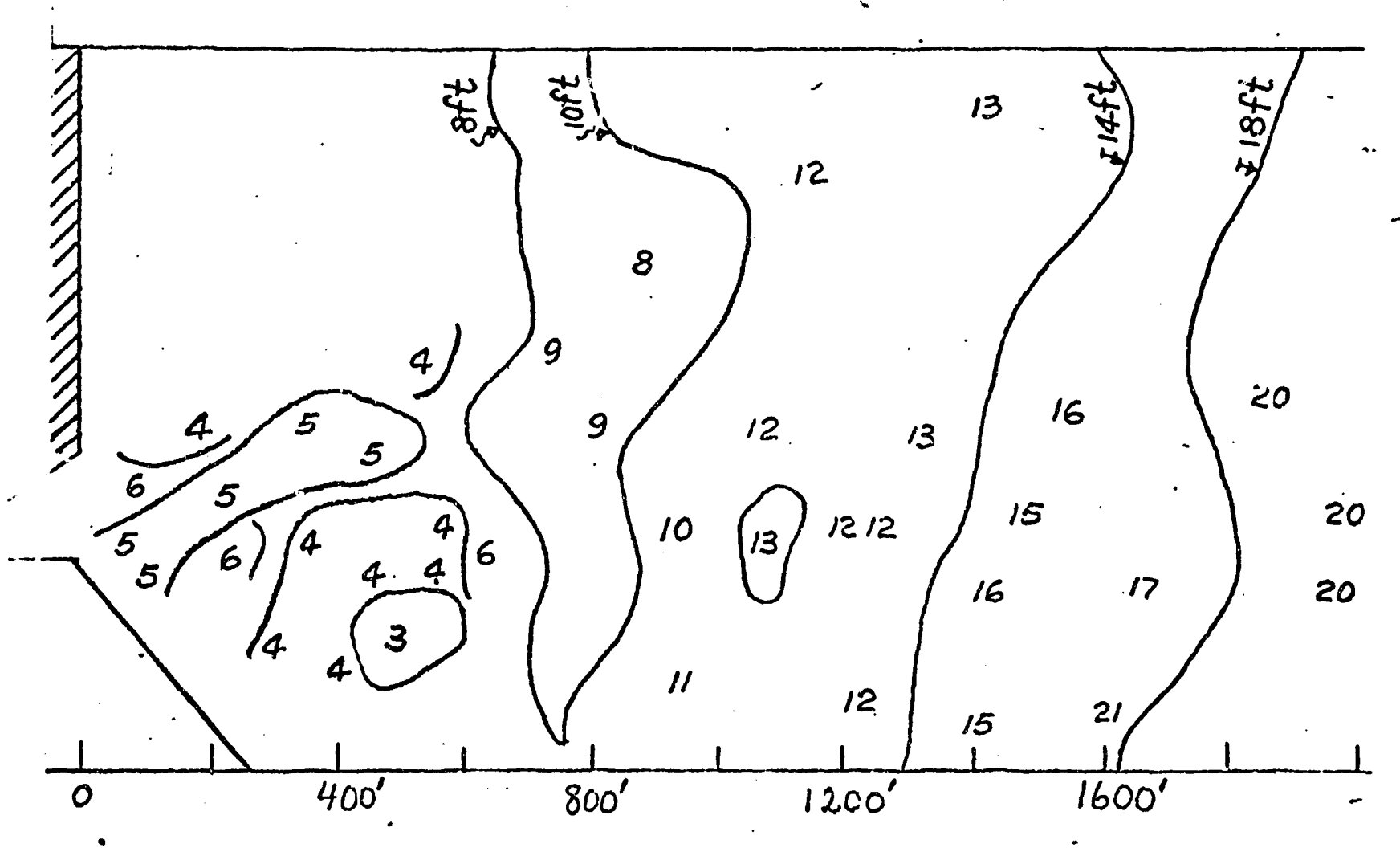

FIG.10 Bottom contours at the Waukegan Pool
Numbers indicate depth in feet. 

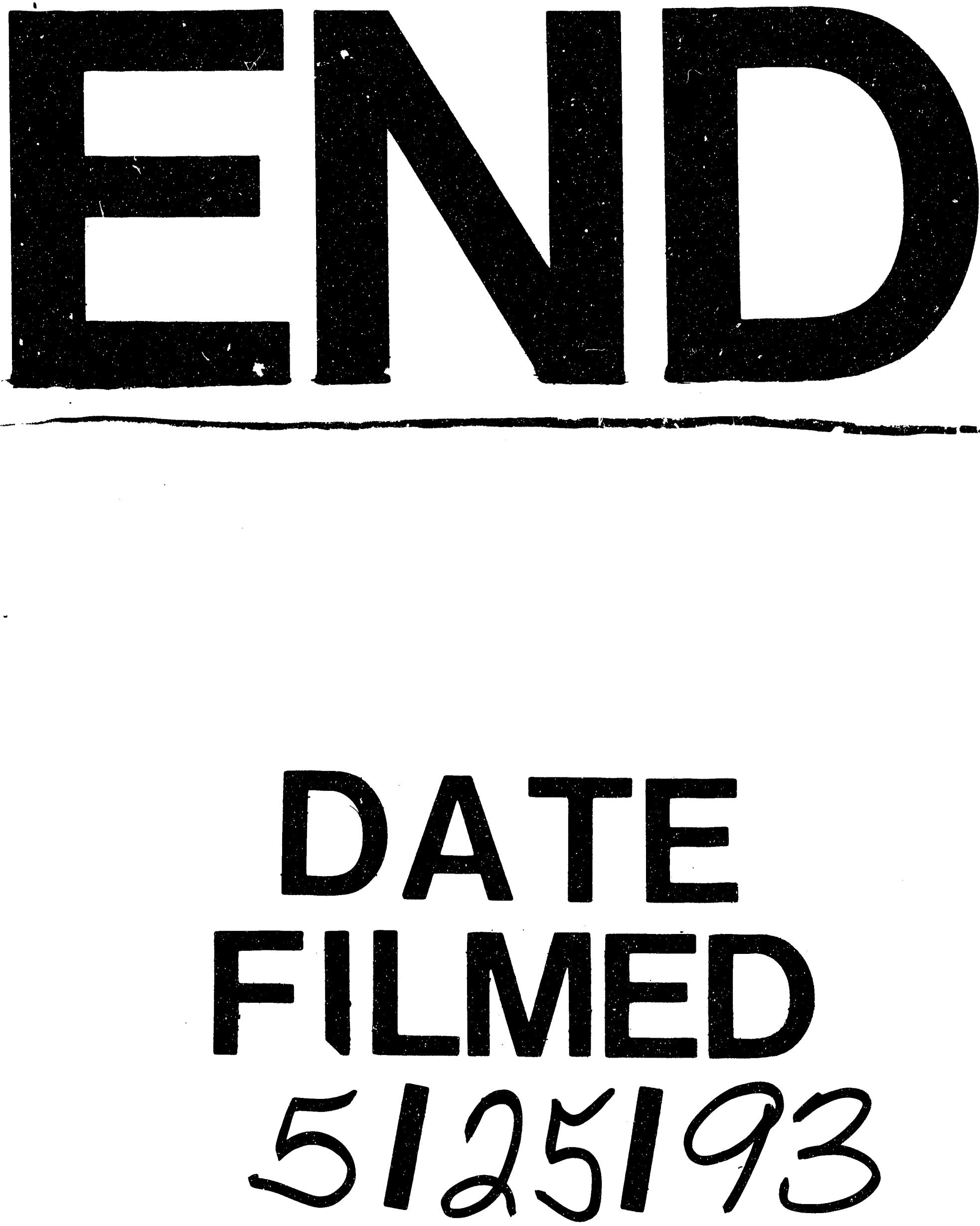
